\title{
Effect of Yoga Exercise on Cortisol Hormone Levels in Pregnant Women in Kinik Pratama
} Asih Waluyojati Banguntapan Bantul Yogyakarta

\author{
Ratih Kumorojati ${ }^{1}$, Alfie ${ }^{1}$, Agus Warseno ${ }^{2}$
}

\begin{abstract}
1'Department of Health Universitas Jenderal Achmad Yani Yogyakarta, Jalan Brawijaya, Ringroad Barat, Ambarketawang, Gamping, Sleman 55294

${ }^{2}$ Department of Nursing Universitas Jenderal Achmad Yani Yogyakarta, Jalan Brawijaya, Ringroad Barat, Ambarketawang, Gamping, Sleman 55294 Email: ratihkumorojati@gmail.com
\end{abstract}

\begin{abstract}
Abstrak
Angka kematian ibu pada tahun 2016 naik dibandingkan tahun 2015. Penyebab kematian ibu pada Tahun 2016 adalah Pre-eklampsia Berat (PEB) sebanyak 33\% (4 kasus), Pendarahan sebesar 17\% (2 kasus), Gagal Jantung 17\% (2 kasus), Sepsis 17\% (2 kasus) dan Lainnya 16\% (2 kasus). Beberapa penelitian menyatakan bahwa preeklamsia terjadi karena pengaruh kecemasan pada masa kehamilan. Kehamilan adalah periode krisis yang melibatkan juga faktor psikologis, perubahan hormon menyebabkan emosi ibu menjadi labil. Selain faktor fisik, faktor psikososial dapat menambah kecemasan pada ibu hamil. Stres yang tinggi dalam kehamilan dapat meningkatkan hormon stres, juga dapat menyebabkan peningkatan tekanan darah dan penurunan berat badan lahir. Tindakan percegahan dapat dilakukan oleh ibu hamil agar memiliki kondisi sehat baik ibu dan janinnya, serta melewati proses persalinan normal yaitu dengan berolahraga, senam, menari, dan yoga. Pada saat ini yoga menjadi salah satu self help yang dapat menunjang proses kehamilan, kelahiran. Fisiologis dari yoga yang dilakukan pada masa hamil adalah membalikkan efek stress yang melibatkan bagian parasimpatik dari sistem syaraf pusat. Efek stres tersebut akan dihambat dengan cara relaksasi, sehingga hormon yang menyebabkan disreguasi tubuh (kortisol) akan berkurang jumlahnya. Hormon kortisol merupakan hormon yang meningkat pada kecemasan sehingga dengan mengedalikan hormon ini dapat menurunkan tingkat kecemasan ibu hamil yang berdampak pada penurunan risiko PEB. Tuhuan nya yaitu melihat pengaruh latihan Yoga terhadap kadar hormon kortisol pada ibu hamil. Jenis penelitian ini adalah penelitian kuantitatif dengan metode penelitian true-experimental, dengan desain Posttest-Only with Control Group. Responden yang digunakan ibu hamil yang mengikuti yoga prenatal, sampel diambil dengan rumus Freeder diperoleh 16 ibu hamil dengan kontrol sebanyak 16. Data dianalisis dengan uji Pearson Chi-Square dengan hasil $p<0,00$ sehingga menunjukkan ada korelasi. Ada pengaruh yoga terhadap kadar kortisol pada ibu hamil
\end{abstract}

Kata Kunci yoga; kortisol; hamil

Abstract
Maternal mortality rates in 2016 rose compared to 2015. The causes of maternal death in
2016 were Severe Preeclampsia (PEB) as much as 33\% (4 cases), Bleeding by $17 \%$ (2
cases), Heart Failure $17 \%$ (2 cases), Sepsis 17\% (2 cases) and Other $16 \%$ (2 cases). Some
studies state that preeclampsia occurs due to the influence of anxiety during pregnancy.
Pregnancy is a period of crisis that involves also psychological factors, hormonal
changes causing the mother's emotions to become lame. In addition to physical factors,
psycho social factors can add anxiety in pregnant women. High stress in pregnancy can
increase stress hormones, it can also lead to increased blood pressure and birth weight


loss. Prevention can be done by pregnant women to have a healthy condition both the mother and her fetus, as well as through the normal labor process that is by exercising, gymnastics, dancing, and yoga. At this time yoga becomes one of the self help that can support the process of pregnancy, birth. Physiological of yoga performed during pregnancy is reversing the effects of stress involving the parasympathetic part of the central nervous system. The effects of such stress will be inhibited by relaxation, so that the hormones that cause body dysregulation (cortisol) will be reduced in number. The hormone cortisol is an increased hormone in anxiety so by masterminding this hormone can lower the anxiety levels of pregnant women which has an impact on the decreased risk of PEB. Look at the effect of Yoga exercise on cortisol hormone levels in pregnant women. This type of quantitative research is True Experimental research method, with Posttest-Only Control Group Design. Respondents who used pregnant women who participated in prenatal yoga, samples taken with the Formula Freeder obtained 16 pregnant women with control as many as 16. Data analysis was performed using the Pearson Chi-Square test with a result of $p<0.00$ which indicates a correlation. There is an effect of yoga on cortisol levels in pregnant women.

Keywords : yoga; cortisol, pregnant

Article info:

Article submitted on September 15, 2020

Articles revised on October 20, 2020

Articles received on December 31, 2020

DOI: http://dx.doi.org/10.21927/jnki.2020.8(4).292-297

\section{INTRODUCTION}

Maternal mortality rates in 2016 rose compared to 2015 . This is marked by a decrease in maternal mortality, if in 2016 amounted to 97.65/100,000 Births. There were 12 cases in 2015 , while in 2015 there were 11 cases of $87.5 / 100,000$. The Results of the Perinatal Maternal Audit (AMP) concluded that the causes of maternal death in 2016 were Severe Preeclampsia (PEB) by 33\% (4 cases), Bleeding by $17 \%$ ( 2 cases), Heart Failure $17 \%$ (2 cases), Sepsis $17 \%$ ( 2 cases) and Others 16\% (2 cases) (1).

Some studies state that preeclampsia occurs due to the influence of anxiety during pregnancy (2-3). Pregnancy is a period of crisis involving also psychological factors, hormonal changes causing the mother's emotions to become lame. In addition to physical factors, psycho social factors can add anxiety in pregnant women (4). Anxiety is considered a risk factor for preeclampsia (5). High stress in pregnancy can increase stress hormones, can also lead to increased blood pressure and weight loss born (6-7). Prevention can be done by pregnant women to have a healthy condition both the mother and her fetus, as well as through the normal labor process that is by exercising, gymnastics, dancing, and yoga. Yoga is a type of body, mind and mental exercise that greatly helps pregnant women flex joints and calm the mind (8).

At this time yoga becomes one of the self help that can support the process of pregnancy, birth, and even parenting that can be done in yoga prenatal classes(9). Physiological of yoga performed during pregnancy is reversing the effects of stress involving the parasympathetic part of the central nervous system. But it will be inhibited by relaxation and hormones that cause body dysregulation (cortisol) will decrease in number. The working function of the parasympathetic nervous system is contrary to the sympathetic nerve, thus slowing down 
the work of the body's internal tools, having the effect of lowering heart rate, breath rhythm, blood pressure, muscle tension, metabolic rate, and production of stress-causing hormones. Along with the decrease in levels of stress-causing hormones, the whole body begins to function at a healthier level with energy (10).

The results of a preliminary study conducted in August 2019 at Klinik Pratama Asih Waluyojati found there were 25 pregnant women where $70 \%$ complained of back pain, back pain, buttock pain, symphysis pubis dysfunction, constipation, shortness of breath, edema, knee pain and fetal apposition. In fact, pregnancy is physiological with these complaints, but the perceived complaints will greatly interfere with the comfort of pregnant women and can trigger anxiety to stimulate the production of cortisol hormone that can aggravate the condition of the mother even the fetus.

The results of previous studies showed that there was a difference that approached the cortisol levels before and after the intervention in pregnant women who followed Yoga which decreased by -209.67 ng / ml (11). The combination of Yoga and spiritual awareness can also lower blood glucose levels and lower cortisol levels but not stress levels (12).

This study aims to measure levels of the hormone cortisol in pregnant women who do prenatal yoga. Unlike previous studies that focused on stress, this study focused more on cortisol in relation to preeclampsia. This study refers to previous studies which revealed that preeclampsia occurs due to the influence of anxiety during pregnancy. The absence of anxiety will trigger the production of the hormone adrenaline or adrenaline or epinephrine norepinephrine which can result in the body's biochemical dysregulation. As a result, pregnant women show symptoms of heart palpitations, increased blood pressure, emotional changes that can even lead to premature contractions during pregnancy, hyperemesis miscarriage, and eclampsia which of course will be very life threatening to pregnant women and even lead to death.

\section{MATERIALS AND METHODS}

This type of quantitative research is True Experimental research method, with PosttestOnly Control Group Design. The research site will be held at Klinik Pratama Asih Waluyo Jati Banguntapan Bantul Yogyakarta. The time of research is 6 months from March to July 2020. The population is pregnant women who participate in yoga at Klinik Pratama Asih Waluyo Jati. The inclusion criteria were pregnant women in the third trimester while the exclusion criteria were pregnant women with complications. Respondents in this study were pregnant women who participated in prenatal yoga, samples taken with the Freeder Formula obtained 16 pregnant women with as many as 16 controls. Measurement of the hormone cortisol in yoga respondents was carried out after participating in yoga 4 times in a row every week, while the measurement in the control group was carried out at week 4 without intervention. Measurement of the hormone cortisol is done by taking venous blood and then laboratory tests at the UGM Clinical Pathology Laboratory

\section{RESULTS AND DISCUSSION}

Based on Table 1, the majority of respondents who followed yoga had normal cortisol levels (93.75\%) with an average of 40.68 , while respondents who did not follow yoga were majority abnormal (81.25\%) with an average of $384.19 \mathrm{nag} / \mathrm{mol}$. The average difference in cortisol in both groups was $343.51 \mathrm{nag} / \mathrm{mol}$.

Based on Table 2 known Asymp values. Sig. (2-sided) on the Pearson Chi-Square test is 0.000 . Because of the value of Asymp. Sig (2-sided) $0.000>0.05$, then based on the above decision-making basis, it can be concluded that distributed data is normal. 
Tabel 1. Distribution and Average Cortisol Values

\begin{tabular}{ccccccc}
\hline & Normal & Percentage & Abnormal & Percentage & Average Percentage of Cortisol Levels \\
\hline Yoga & 15 & 93,75 & 1 & 6,25 & 40,68 & 343,51 \\
Control & 3 & 18,75 & 13 & 81,25 & 384,19 & \\
\hline
\end{tabular}

Tabel 2. Results of Chi-Square Test

\begin{tabular}{lccc}
\hline & Value & df & $\begin{array}{c}\text { Asymp. Sig. } \\
\text { (2-sided) }\end{array}$ \\
\hline Pearson Chi-Square & $21.895^{\mathrm{a}}$ & 1 & .000 \\
Continuity Correction $^{\mathrm{b}}$ & 18.656 & 1 & .000 \\
N of Valid Cases $^{\mathrm{b}}$ & 32 & & \\
\hline
\end{tabular}

Based on table 3 known sig values. (2-tailed) in the yoga group is $0.000<0.005$, then $\mathrm{HO}$ is rejected and $\mathrm{Ha}$ is accepted. Thus, it can be noted that there is an effect of yoga practice with cortisol levels in pregnant women at Pratama Asih Waluyo Jati Banguntapan Bantul Clinic Yogyakarta. This can mean that the more a yoga exercise routine will keep cortisol levels at normal range, thus the less a yoga exercise routine will increase cortisol levels.

Tabel 3 Results of Independent Sample Test

\begin{tabular}{cccc}
\hline & $\mathrm{N}$ & Mean & Sig (2-tailed) \\
\hline Yoga & 16 & 1.00 & .000 \\
Control & 16 & 1.81 & .000 \\
\hline
\end{tabular}

\section{Discussion}

The results showed the influence of yoga with cortisol levels in pregnant women with $p<0.05$. This is supported by the theory that yoga practice is linked by an increase in Gamma Amino Butyric Acid (GABA) (13). GABA is a neurotransmitter that plays an important role in symptoms of mental disorders. Gaba's main function is to lower aurosal and reduce aggression, anxiety and be active in excitation function (14). Yoga is a unique method of balancing the autonomic nervous system and exerting influence on physical disorders and stress-related disorders (15). Yoga breathing techniques lead to increased parasympathetic work thus suppressing catecholamine production (epinephrine and norepinephrine) and providing a calm effect, stimulating the release of oxytocin. Decreased catecholamine causes vasodilation of blood vessels and facilitates blood distribution every minute and can lower blood pressure and reduce oxidative stress. It also mentioned that with three weeks of yoga breathing exercises led to a significant decrease in cortisol hormone production (16).

Practicing yoga every day can facilitate blood circulation, because the sense of relaxation gained from yoga helps smooth blood circulation in the body, so it is very beneficial for hypertension sufferers. This yoga is shown to increase b-endorphin levels four to five times in the blood. Ab-endorphine will come out and be captured by receptors in the hypothalamus and limbic system that serves to regulate emotions. The decrease in blood pressure is caused by relaxation in yoga the principle is to position the body in energy conditions, so that it will increase oxygen circulation to the muscles and the muscles will loosen, blood pressure will decrease (17).

Studies have shown that fetuses of exercising women may tolerate labor better than those of nonexercisers (18). It has been suggested that regular physical activities may protect against preeclampsia by intervening at three key stages in the disease process: 1) enhanced placental growth and vascularity (protection against abnormal placental development), 2) reduction of oxidative stress, and 3 ) reversal of endothelial dysfunction (19). An integrated approach to yoga during pregnancy improved birth weight, decreases preterm labor, and decreases intra uterine growth retardation (IUGR) either in isolation or associated with pregnancy-induced hypertension, with no increased complications (20). 
It is possible that alteration of maternal sympathetic nervous system functioning, as demonstrated by reduced levels of stress-related hormones such as cortisol, may be one of the mechanisms through which yoga initiates psychophys- iological change in pregnant women. An integrated yoga program, including asana, pranayama, and dharana, guided relaxation, and yogic theory in application to pain states, has been shown to alter cortisol levels in a sample of females with chronic pain due to fibromyalgia (18). Yoga has also been shown to reduce inflammatory markers, decrease heart rate, and produce improvements in physical fitness variables, all of which may work in concert with behavioural change and psychosocial functioning to improve reactivity to stress and pain (21).

\section{CONCLUSION AND RECOMMENDATION}

There was an average difference in cortisol hormone levels in the pregnant women intervention and control group where the number of pregnant women with normal cortisol levels was more than control group. Average cortisol levels in respondents with yoga were lower than he control group but it fell within the normal range. Effective yoga exercises can cause cortisol in pregnant women. Pregnant women with high levels of the hormone cortisol have a 20 times greater tendency to experience gestational hypertension than pregnant women with normal cortisol levels. From some risk factors, stress levels are significantly at risk of increasing the hormone cortisol. Pregnant women who experienced stress were 12 times more at risk of an increase in the hormone cortisol than mothers who did not experience stress.

The results of this study are expected to be used as a useful source of science about the effect of yoga practice on cortisol hormone levels in pregnant women. Advice for Midwifery Institutions is expected to hold learning programs or training on complementary therapy, especially yoga. Respondents are expected to practice yoga movements in daily activities or participate in yoga exercises at the nearest BPM to lower cortisol hormone levels.

\section{REFERENCES}

1. Dinas Kesehatan Kabupaten Bantul. Profil Kesehatan tahun 2017. Pemerintah Kabupaten Bantul: Dinas Kesehatan; 2018.

2. Hu, R., LI,Y,Zhang, Z. \& Yan, W. Antenatal depressive symptoms and the risk of preeclampsia or operative deliveries: a metaanalysis. PloS one, 10, e0119018; 2015.

3. Sharda Ghoghre. Anxiety and the Risk of Hypertensive Disorder during Pregnanc; 2016.

4. Gross, H. \& Helen, P. Researching Pregnancy: Psychological Perspective, New York: Routledge; 2007.

5. Kordi, M., Vahed, A., Rezaee Talab, F., Mazloum, S. R. \& Lotfalizadeh, M. Anxiety during pregnancy and preeclampsia: a case-control study. Journal of Midwifery and Reproductive Health, 5, 814-820; 2017.

6. Harville, E. W., Savitz, D. A., Dole, N., Herring, A. H., Thorp, J. M. \& Light, K. C. Patterns of salivary cortisol secretion in pregnancy and implications for assessment protocols. Biological Psychology, 74, 85-91; 2007.

7. Satyapriya, M., Nagendra, H. R., Nagarathna, R. \& Padmalatha, V. Effect of integrated yoga on stress and heart rate variability in pregnant women. International Journal of Gynecology \& Obstetrics, 104, 218-222; 2009.

8. Krisnadi, Sofie Rifayani. Sinopsis Yoga Untuk Kehamilan: Sehat, Bahagia Dan Penuh Makna. http://www.bukukita.com. Jakarta; 2010.

9. Depkes RI. Strategi akselerasi pencapaian target MGDs 2015retrieved fromhttp://www. target_mgds; 2010. 
10. Streeter, C. C., Gerbarg, P. L., Saper, R. B., Ciraulo, D. A. \& Brown, R. P. Effects of yoga on the autonomic nervous system, gamma-aminobutyric-acid, and allostasis in epilepsy, depression, and post-traumatic stress disorder. Med Hypotheses, 78 (5): 571-9; 2012.

11. Saridewi, E., Suwondo, A., Wahyuni, S. Pengaruh Kombinasi Yoga Prenatal Dan Senam Hamil Terhadap Perubahan Kadar Kortisol Dan Lama Persalinan Kala I. Jurnal Tunas-tunas Kesehatan, 7(4):288-292; 2017.

12. Lestari, T.P. Pengaruh Kombinasi Yoga Dan Spiritual Mindfulness Terhadap Penurunan Kadar Glukosa Darah, Kortisol Dan Stres Klien Diabetes Melitus Tipe II. Thesis. Universitas Airlangga

13. Streeter, C. C., Gerbarg, P. L., Saper, R. B., Ciraulo, D. A. \& Brown, R. P. (2012) Effects of yoga on the autonomic nervous system, gamma-aminobutyric-acid, and allostasis in epilepsy, depression, and post-traumatic stress disorder. Med Hypotheses, 78 (5): 571-9

14. Subu, Arsyad. 2011. Anatomi Otak dan Neurophysiopshycology dan Gangguan Jiwa, (Online), (http:// www.google.co.id, diakses: Agustus 2020).

15. Hamdiah, Suwondo A, Hardjanti TS, Soejoenoes A, Anwar MC. Effect of prenatal yoga on anxiety, blood pressure, and fetal heart rate in primigravida mothers. Belitung Nursing Journal. 3(3):246-54; 2017.

16. Sindhu., Panduan Lengkap Yoga: Untuk Hidup Sehat dan Seimbang. Bandung: Penerbit Qanita; 2014.

17. Paisley TS, Joy EA, Price RJ., Jr Exercise during pregnancy: A practical approach. Curr Sports Med Rep. 2003;2:325-30. [PubMed: 14583162]

18. 11. Weissgerber TL, Wolfe LA, Davies GA. The role of regular physical activity in preeclampsia prevention. Med Sci Sports Exerc. 2004;36:2024-31.

19. Narendran S, Nagarathna R, Narendran V, Gunasheela S, Nagendra HR. Efficacy of Yoga on pregnancy outcome. J Altern Complement Med. 2005;11:237-44.

20. K. Curtis, A. Osadchuk, and J. Katz, "An eight-week yoga intervention is associated with improvements in pain, psycho- logical functioning and mindfulness, and changes in cortisol levels in women with fibromyalgia," Journal of Pain Research, vol. 4, pp. 189201, 2011.

21. A. A. Wren, M. A. Wright, J. W. Carson, and F. J. Keefe, "Yoga for persistent pain: new findings and directions for an ancient practice," Pain, vol. 152, no. 3, pp. 477-480, 2011. 